УдК 640.43

\title{
Large Wildfires in Taiga Subzones of Central Siberia
}

Erik N. Valendik ${ }^{a}$, Sergey V. Verkhovets ${ }^{\text {a, }}$, Eugene I. Ponomarev ${ }^{a}$, Vera A. Ryzhkova ${ }^{a}$ and Yegor K. Kisilyakhova* ${ }^{a}$ V.N. Sukhachev Institute of Forest SB RAS 50/28 Akademgorodok, Krasnoyarsk, 660036, Russia ${ }^{b}$ Siberian Federal University, 79 Svobodny, Krasnoyarsk, 660041, Russia

Received 12.10.2013, received in revised form 08.12.2013, accepted 19.02.2013

The work deals with the nature of large wildfires, conditions of their occurrence and distribution in the taiga of Central Siberia. The large fires in this region occur during periods of prolonged and intense drought, with precipitation deficit more than $60 \%$ of the norm. Vegetation and climate conditions of large fires are identified and map of their distribution is compiled using satellite information. Fire seasons scenarios are examined, and an iterative model for short-term forecasting of extreme fire situations is proposed. Methodology for short-term forecasting of large wildfires risk is offered based on satellite data simultaneously on the whole territory of Central Siberia.

Keywords: large ${ }^{l}$ and catastrophic ${ }^{2}$ forest fires, droughts, extreme fire season.

Research was carried out with the support of the grant of the Russian Science Foundation (project 14-24-00112 and 13-05-41506 [1])

(c) Siberian Federal University. All rights reserved

* Corresponding author E-mail address: ykisi188@gmail.com 


\title{
Природа крупных пожаров
}

\section{в подзонах тайги Центральной Сибири}

\author{
Э.Н. Валендика, С.В. Верховец ${ }^{\mathrm{a}, \boldsymbol{\sigma}}$, \\ Е.И. Пономарев ${ }^{\text {a }, ~ В . А . ~ Р ы ж к о в а ~}{ }^{\text {a }}$ Е.К. Кисиляхов ${ }^{\text {a }}$ \\ ${ }^{a}$ Институт леса им. В.Н. Сукачёва СО РАН \\ Россия, 660036, Красноярск, Академгородок, 50/28 \\ ${ }^{6}$ Сибирский федеральный университет \\ Россия, 660041, Красноярск, пр. Свободный, 79
}

В статье рассматриваются вопросы природы пожаров, условия их возникновения и распространения в подзонах тайги Центральной Сибири. Установлено, что крупные пожары в этом регионе возникают в периоды длительных и интенсивных засух с недобором осадков более 60 \% от нормы. Выявлены растительные и климатические условия распространения крупных пожаров и составлена карта их распределения по территории по космической информации. Рассмотрены сиенарии развития пожароопасных сезонов, предложены итерационная модель краткосрочного прогнозирования экстремальной пожароопасной обстановки и методика краткосрочного прогноза опасности возникновения ландшафтных пожаров по спутниковым данным одновременно на всей территории Центральной Сибири.

Ключевые слова: крупные и катастрофические лесные пожары, засухи, экстремальный пожароопасный сезон.

Исследование выполнено при поддержке гранта Российского научного фонда (проект 14-2400112 и 13-05-41506 [1]).

\section{Introduction}

Russian forests up to $2-17$ million hectares are affected by wildfires annually (Korovin, 1996; Valendik, 1996; Conard et al. 2002; Soja et al. 2004; Shvidenko et al., 2011; Ponomarev, Shvetsov, 2013). Although large and catastrophic fires make up about 1-2 \% of all forest fires, they account for up to $50-70 \%$ of the total area burned and up to $90 \%$ of the total fire damage (Valendik, 1996).

Increase in large wildfires activity and the area burned growth has been observed during previous years (Loupian et al., 2006, Sukhinin, 2008; Goldammer et al., 2013). Large wildfires (with areas burned exceeding 1400 ha) have occurred mainly in northern boreal forests of
Central and Eastern Siberia. In 2012 and 2013, most large wildfires in Russia have occurred in Yakutia, Evenkiya, Khanty-Mansyisk and north of Krasnoyarsk Regions (Ponomarev, Shvetsov 2013).

Forest fire growth to large and catastrophic size can be attributable to certain combinations of natural and human factors. Natural factors include vegetation, topography, and weather characteristics. Human factors are mostly organizational and technical by character, mainly availability of fire suppression resources and effective resource use technologies. Investigating processes of fire growth to large or catastrophic sizes is based upon analysis of zone-specific vegetation, topography, and synoptic events. 
Forest cover in areas of the boreal forest is extremely mosaic and when the fire spread to tens, hundreds and even thousands of hectares during long droughts, all the numerous forest formations, characteristic of this forest area are subjected to burning. The development of fire and its spread is determined not by individual types of forest combustible materials, but by a complex of natural factors, including forest cover, topography, climate, current weather, synoptic situation and characteristics of the landscape. Under these conditions, the fires have covered landscape elements, whole landscapes and even landscaped area. These natural formations and fires spreading there well defined on the satellite imagery (Sukhinin et al., 2003; Sukhinin, 2008; Balzter et al., 2010; Rubtsov et al., 2010). With the use of satellite imagery in the thermal range, you can also evaluate the fire environment simultaneously over a wide area.

Usually, all large fires occur in anomalous hydro meteorological conditions, namely, in a drought. The duration and intensity of drought (precipitation deficit) are the background upon which forest fires occur and spread in boreal landscapes.

Intense drying occurs not only in surface flammable materials (forest litter, mosses and lichens) but also including lower layers (litter, peat) in long droughts. The drying affects the exposed parts of the forest, which in normal years do not burn and are obstacles to the fire spread (floodplains, swamps and other areas with excessive moistening). This leads to the fact that the fire natural barriers disappear across the landscape, and that is the main reason for the development of large fires. Thus, the problem of large fires connected with the problem of droughts.

Accurate and detailed chronology of such situations in geographical and temporal aspects gives the opportunity to deliberately plan the fire prevention and fire fighting capabilities to concentrate in specific regions.

The main aim of the paper was to investigate the conditions that cause occurrence of large-scale wildfires and detailed analysis of the formation and forecast of extreme fire danger regimes.

\section{Materials and Methods}

The objects were large and catastrophic fires and vegetation as well, and combustion processes of forest cover under anomalous weather conditions in the Central Siberian taiga subzones.

For spatial evaluation of wildfires distribution we used physical-geographical zoning map, vegetation map with scale 1: 7500000 (Isaev et al., 1994), landscape map with scale 1: 2500000 (Gudilin, 1987) and the layout of the map of the forest vegetation of the Krasnoyarsk region with scale 1: 2500000, images of fires with the satellite "Meteor-30", as well as detected fires database in thermal range with NOAA, TERRA on the whole territory of Central Siberia since 1996 to 2012 years. For the analysis of fires we used data with burned areas more than 1400 hectares, representing more than 14 on the satellite image pixels. Area burned estimation errors of such wildfires according to the satellite detection is not higher than 5-7\% (Sukhinin, 1996; Loupian et al., 2006). Fires with such burned area usually occur only during long droughts.

During the reconstruction of anomalous hydro meteorological conditions (drought) and the reasons for their appearance on the territory of Central Siberia we used data from Central Siberian Department for hydrometeorology and environmental monitoring and from (Breshkova et al., 2011; Chekmasova, 2002; Grechikhina et al., 2003; Kotilevskaya, 2010; Satina, 2012; Vasiliev et al., 2006). 


\section{Results and Discussion}

Large wildfires

\section{and meteorological anomalies}

An indicator of large and catastrophic forest fires emergence constitute anomalous weather conditions as droughts, their duration and intensity (precipitation deficit for summer fires more than $50 \%$ of the norm).

The largest areas were fixed in the northern taiga fires in June 1979, and in August 1984 (Table 1). The largest by area burned extreme fire season recorded in July 2006, when large fires occurred in all subzones of taiga, and the maximum number and area burned were registered in light coniferous forests of middle taiga.

In the northern taiga prolonged and intense drought, with precipitation deficit of up to $80 \%$ was observed in June 1979 and August 1984. In these years the fires spread to hundreds thousands of hectares.

In 2006, drought swept across the landscapes of northern, central and northern parts of the southern taiga. Precipitation deficit in the region in July and August was between 66 and $88 \%$. It was the most prolonged and intense drought in Central Siberia for the whole 10-year period.

In mountain taiga, in its southern part (Republic Tyva) drought was observed in July and August 2002, here major fires occurred and spread in the larch forests. The most frequent droughts are observed in the southern taiga (about 1 every three years) and there are large fires even at the relatively short droughts with precipitation deficit less than $50 \%$. Most of these fires involve logged areas and herbal forest types in May-June.

Causes of drought in Central Siberia are directly associated with the planetary atmospheric circulation in the northern hemisphere.

In August 2002, the drought in the southern part of the mountain taiga was formed by spurs of the Azores anticyclone centered in the upper Volga region of Russia. The spur pressure exceeded the monthly multiyear average by 6-7 $\mathrm{hPa}$. It contributed to a very warm and even hot weather (3-4 degrees above normal), with predominance of precipitation deficit up to $80 \%$ in the East of the Asian continent: in the Tyva Republic, Irkutsk and Chita regions, Buryatia and the north-western part of Mongolia (Chekmasova, 2002).

May, 2003: in the middle troposphere sustained high-altitude valleys were formed in the North Atlantic and Eastern Europe, and highaltitude anticyclone ridges spread over the central regions of Siberia (Grechikhina et al., 2003). This has resulted in the northern part of south taiga of Central Siberia (Angara River region) formation of the pressure ridges, where the pressure was higher than the norm by 3-5 $\mathrm{hPa}$. This provided there anomalous dry hot weather, with temperatures exceeding $30^{\circ} \mathrm{C}$.

July 2006. In the middle stratosphere of the northern hemisphere, anticyclonic vortex has intensified with the centre under the North Pole (Vasiliev et al., 2006). His positive anomalies over Siberia contributed to the establishment in the taiga zone of Central Siberia except mountain taiga warm and even hot weather with temperatures up to $32-34^{\circ} \mathrm{C}$, with a precipitation deficit up to $72 \%$. During this period, there arose and spread dozens of large forest fires.

July 2010, dry and hot weather in the European part of Russia has formed by intense Azores anticyclone (Kotilevskaya, 2010). Its pressure ridge in July and August was as an independent anticyclone, which has blocked the European part of Russia from the Atlantic cyclones and created here anomalous hot and dry weather, which led to a prolonged drought and many catastrophic wildfires. The extreme wildfire situation over the European part of Russia resulted in 2.2 million hectares of land affected by wildfires (Bondur, 2011). Main reason of these droughts could be explained by atmospheric Rossby waves (Bondarenko, 2013). 
Table 1. The natural conditions of large wildfires distribution in boreal forests

\begin{tabular}{|c|c|c|c|c|c|}
\hline $\begin{array}{l}\text { Month, } \\
\text { year of fire }\end{array}$ &  & 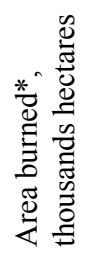 & 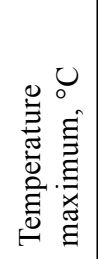 &  & Synoptic characteristics \\
\hline \multicolumn{6}{|c|}{ Northern taiga } \\
\hline June, 1979 & 50 & 500 & 30 & 80 & $\begin{array}{l}\text { Slow moving anticyclone slope with center near Tura } \\
\text { settlement }\end{array}$ \\
\hline August, 1984 & 30 & 400 & 27 & 73 & $\begin{array}{l}\text { Anticyclone with cold front pass with center near } \\
\text { Salekhard }\end{array}$ \\
\hline July, 1999 & 34 & 145 & 28 & 64 & Low gradient baric field of low pressure over Ob River delta \\
\hline July, 2006 & 79 & 781 & 30 & 70 & $\begin{array}{l}\text { Anticyclone slope centered in Novaya Zemlya Island with } \\
\text { cold front and occlusion front passes }\end{array}$ \\
\hline August, 2012 & 25 & 280 & 27 & $>80$ & Vast anticyclone over North Pole \\
\hline \multicolumn{6}{|c|}{ Central taiga } \\
\hline July, 1999 & 66 & 212 & 28 & 68 & Low gradient baric field of low pressure over North Pole \\
\hline July, 2006 & 119 & 1300 & 30 & 72 & $\begin{array}{l}\text { Anticyclone slope centered in Novaya Zemlya Island with } \\
\text { cold front and occlusion front passes }\end{array}$ \\
\hline August, 2006 & 27 & 215 & 26 & 66 & $\begin{array}{l}\text { Anticyclone slope centered in Novaya Zemlya Island with } \\
\text { cold front and occlusion front passes }\end{array}$ \\
\hline July, August 2012 & 200 & 3000 & $28-35$ & $>80$ & Vast anticyclone over North Pole \\
\hline \multicolumn{6}{|c|}{ Southern taiga, subtaiga } \\
\hline July, 1996 & 36 & 182 & 31 & 88 & $\begin{array}{l}\text { Vast anticyclone centered near Tura and cyclone narrow } \\
\text { front with warm frontal pass from Central Yakutia }\end{array}$ \\
\hline July, 2006 & 84 & 787 & 30 & 70 & $\begin{array}{l}\text { Anticyclone slope centered in Novaya Zemlya Island with } \\
\text { cold front and occlusion front passes }\end{array}$ \\
\hline May, 2011 & 48 & 348 & 28 & 58 & $\begin{array}{l}\text { Anticyclone slope centered in Salekhard with cold front and } \\
\text { occlusion front passes with transition to cyclone trough and } \\
\text { warm front }\end{array}$ \\
\hline $\begin{array}{l}\text { June, } \\
1-14,2011\end{array}$ & 33 & 118 & 30 & 59 & $\begin{array}{l}\text { Anticyclone slope centered in Salekhard with cold front and } \\
\text { occlusion front passes with transition to cyclone trough and } \\
\text { warm front }\end{array}$ \\
\hline June, July 2012 & 121 & 900 & $28-35$ & $>80$ & Vast anticyclone over North Pole \\
\hline \multicolumn{6}{|c|}{ The mountainous southern taiga } \\
\hline May, 1999 & 42 & 300 & 30 & 16 & $\begin{array}{l}\text { Vast anticyclone centered in Lake Baikal and anticyclone } \\
\text { trough centered in Kolpashevo warm front pass }\end{array}$ \\
\hline $\begin{array}{l}\text { July, } 2002 \\
\text { (Republic of Tyva) }\end{array}$ & 23 & 136 & 32 & 48 & $\begin{array}{l}\text { High altitude slope and near land surface powerful spur of } \\
\text { the Azores anticyclone }\end{array}$ \\
\hline $\begin{array}{l}\text { August, } 2002 \\
\text { (Republic of Tyva) }\end{array}$ & 39 & 156 & 26 & 24 & $\begin{array}{l}\text { Migratory high-altitude slopes and high-latitude troughs } \\
\text { under the Azores anticyclone }\end{array}$ \\
\hline
\end{tabular}

- wildfires number and area burned more than 1400 hectares.

May-June 2011. The abnormally warm weather in most of Siberia in May-June was connected with the development of the anticyclone near the North Pole in the third week of April (Breshkova et al., 2011). In the second half of May and early June, blocking anticyclone ridges were formed to the East of Siberia, which set the dry period in the northern part of Central 
Siberia. In the northern taiga subzone of Western Siberia anomalous temperature was $10-11^{\circ} \mathrm{C}$ above the long-term average in Central Siberia. Abnormal temperatures reached $22-29^{\circ} \mathrm{C}$. In the south of Krasnoyarsk region the temperature was increased up to $33^{\circ} \mathrm{C}$, while the precipitation deficit was $45-70 \%$ of the norm.

June-August 2012. The abnormally warm weather in most of Siberia in June-August was connected with the development of the anticyclone near the North Pole in May. In early June, blocking anticyclone ridges were formed to the East of Siberia, which set the dry period in the Central Siberia. In the southern taiga subzone anomalous temperatures in June-July were $10-11^{\circ} \mathrm{C}$ above the long-term average in Central Siberia. Abnormal temperatures reached $28-35^{\circ} \mathrm{C}$. In the central taiga subzone anomalous temperatures in July-August reached $28-35^{\circ} \mathrm{C}$ while in the northern taiga subzone anomalous temperatures were up to $27^{\circ} \mathrm{C}$ in August. During June - August precipitation deficit was more than $80 \%$ of the norm in all taiga subzones (Satina, 2012). In some places precipitation was absent during 2 months. This abnormal drought has led to numerous large forest fires (Table 1).

Thus, droughts and as a consequence large forest fires in the boreal forest of Central Siberia associated with planetary atmospheric circulations mainly anticyclonic trend.

\section{Large wildfires distribution in the boreal forest}

To plan large wildfires control and to forecast their effects, first of all, the peculiarities of their development under specific physiographic, climatic and forest site conditions should be known. The characteristics of natural conditions of large wildfires spread in forest zones of taiga are given in the Table 1 and Fig. 1.

Fires in mountain southern taiga forests. This is the region of mountain- taiga and subgoltsy- taiga Siberian pine and larch forests with patches of taiga- Siberian pine- fir forests as well as subtaiga- forest-steppe larch and Scotch pine stands. The most widespread forest types are: cowberry- true moss, ledum- moss Siberian pine and larch forests; bilberry, bergenia Siberian pine and fir forests; tussock-mossy, tussocklichen, dwarf birch-lichen Siberian pine forests; cowberry rich in herbs, wood-reed - rich in herbs Scotch pine and larch forests; bracken- rich in herbs Scotch pine and birch stands. Such forest conditions indicate that in this region forest fires can occur during the whole snow-free period of time.

Fire start in the mountains is closely connected with the beginning of snow cover disappearance on non-forested southern slopes. It usually occurs in the foothills and low mountainous area in late April and early May. By the second half of May it reaches the midlands but in the alpine zone snow disappears in June and even early in July, for example, in the dark coniferous forests (Sofronov, 1967).

Fires can occur on the treeless southern slopes three to four weeks earlier than on the wooded slopes of other expositions. But in the early melting of snow they are local in nature. As the melting of snow in other slopes fires could start and spread over large areas in the eastern, western, and later on the northern slopes. However, in dry years, fires can occur and spread across the mountainous system regardless of slope, exposition and the character of ground cover.

In the Western Sayan mountains in the midland zone fires occur in treeless areas (old reed-grass logged areas and burned areas on the southern and western slopes) at the II and even I fire danger class (Sofronov, 1967). In grassy type of Siberian Pine stands forest fires are possible only when fire danger reach III class. However, before the end of May fire danger is low on any 


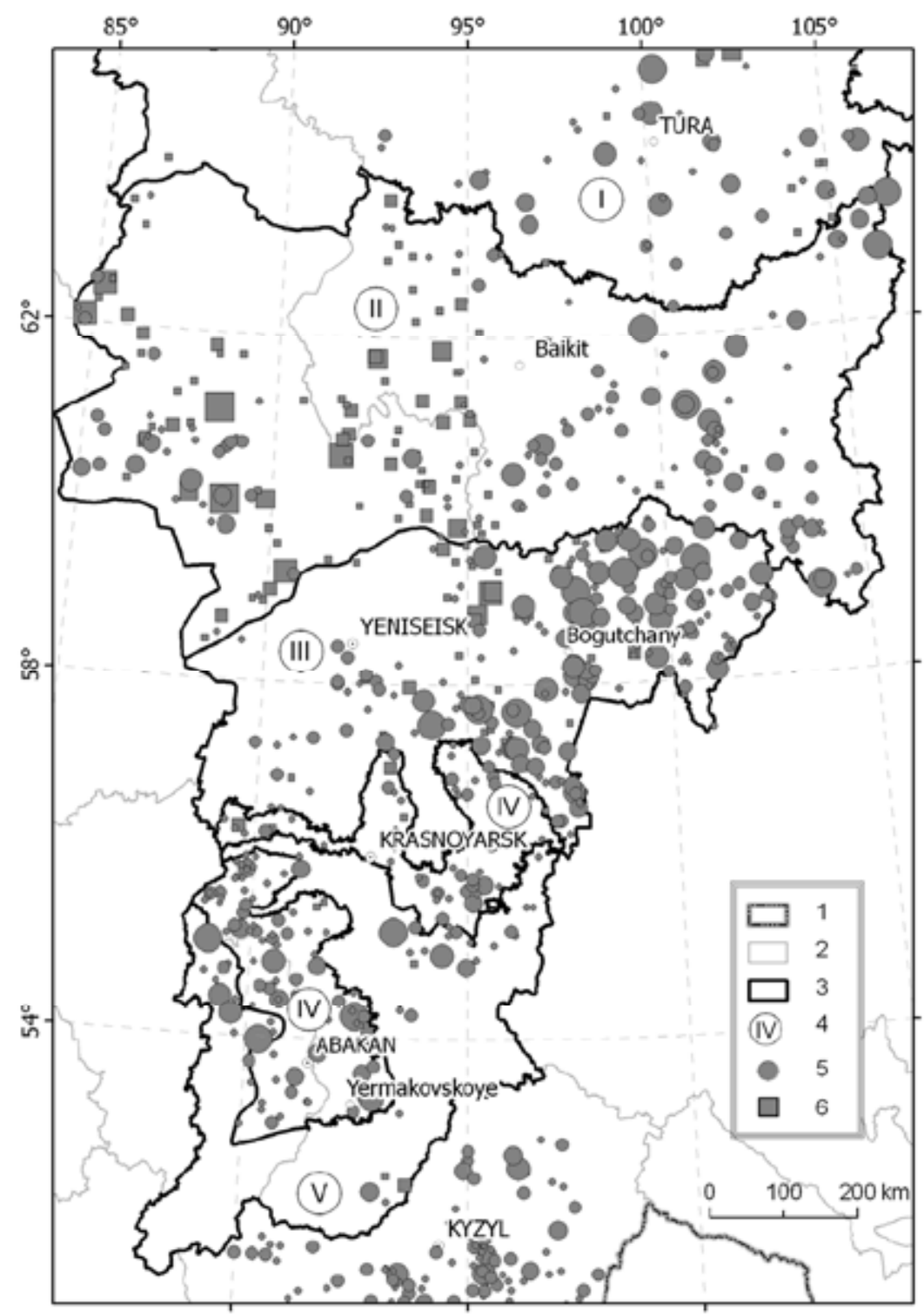

Fig. 1. 1996-2012 area burned in taiga subzones and Republic of Tyva. Legend: 1 - the State border of Russia, 2 the constituent entities of the Russian Federation, 3 - natural zones borders, 4 - natural zone number, I - northern taiga, II - central taiga, III - southern taiga, subtaiga, IV - forest steppe and steppe, V - the mountainous southern taiga, 5 - large scale fire scars of 1996, 1999, 2002, 2003, 2006, 2011, 6 - large scale fire scars of 2012 for comparison (sizes of marks are proportional to area burned)

autumn because of the predominance of tall grass forest groups. During the summer, fires are very rare and appear only in times of prolonged droughts. In spring and autumn in tall grass forest types fire danger occurs when fire danger class is in I and even II. In stands with mossy ground vegetation in the foothills and low mountainous type of forests located on the northern and eastern slopes. In the Western Tannu-Ola mountains because of the dry climate and the prevalence of larch stands with grassy cover forest fires occur on I and II fire danger classes.

In dark coniferous forests of the Kuznetsk Alatau fire danger occurs only in spring and 
part fires start in III class and in the midlands-in classes IV-V. Fires are rare in the highlands and occur only during prolonged droughts.

We have seen the development of large fires in the summer of 1982, after a long period of days without precipitation on the North and South megaslopes of the West Sayan and Tannu - Ola mountains. In the south megaslope of TannuOla, they were distributed along the wide valleys and ravines to mountain ridges and captured the eastern slopes of the spurs. The southern and western steep treeless slopes they bypass, as ground vegetation cover is very rare, but green vegetation prevent fire spread on more gentle slopes.

Fire in the Western Sayan Mountains active on July 13, 1982, spread from the broad valley covering the narrow ravines into two opposite slope watershed ridges, capturing the Eastern and Northern parts, skirting the large southern and western slopes. In the wide ravines because of the presence of large quantities of fuel and coniferous forest regeneration the intensity of fire is high. On the slopes and peaks of the ravines there are crown fires. Very often large fires in the mountains are presented by separate parts not bound by shared edge similar to wildfires in the wetland forests in Western Siberia.

Fires in southern taiga. The most of large wildfires are in Angara region. The territory has an upland relief. Forests are cultivated or cultivation is planned during the next $10-20$ years. The percentage of forest lands is $90 \%$, the percentage of bog lands makes $10 \%$. Grassytrue moss, cowberry, sedge- rich in herbs, lichen and sedge- sphagnum pine and larch forest types are most met here. Birch stands with grass ground vegetation are widely spread. Pine stands are related to the lowlands and are located along the rivers occupying southern slopes. The larch dominates in near watershed territories.
The shaded slopes are covered with mixed dark coniferous true moss forests.

The territory is thoroughly protected and fires having area of more than one thousand hectares are uncommon here. During the dry years the fires can occur from the second half of May and last until September. In such years they can freely spread over the large area. Sedge- sphagnum bogs and large tributaries of the Angara River can be the barriers to the fire spread. Usually fires with area less than 50-100 ha have a round or elliptic shape. The fire perimeter is often disrupted on flank and back edges, however, all its tactical parts remain stable. Mainly fires spread under convective transfer of firebrands.

Fires in the northern taiga forests appear in the third ten- day period of June and in dry seasons can last until the first ten-day period of September, and finish with the first continuous rain and snow falls.

The percentage of forest land is $35 \%$, and the percentage of bogs is $30 \%$. Low mountain tundra and pre-tundra spruce and larch as well as larch open forests grow here. Grassy- dwarf birch, dwarf birch and dwarf shrub - lichen forest types prevail here as well.

The fires occur and spread mainly in shrub/lichen types affected by wind and slopes. They have the round shape with two or more prominent parts formed under the influence of mountain slopes and non-burning bog areas. In a case of prolonged fires the fire perimeter has star-like shapes formed because of wind direction change. The edges of such fires are disrupted; they often spread by front or flanks or just by frontal edge. Fires can also spread only by their back edge. Sometimes it can have several kilometers in length. The rate of spread of fires is small which can be indicated by their round shape which also indicates that the territory is rather homogeneous and the system of natural breaks for fire spread is limited. 
Fires can freely spread to tens of thousands hectares.

Fires in central taiga forests also appear in the same period as in northern taiga. The territory has an upland relief, the percentage of forest lands makes $70-80 \%$, the percentage of bog lands is $15 \%$. The territory is covered mainly by pure larch stands and larch stands mixed with fir, spruce, pine and birch. Such stands are most spread here: shrub- moss, true moss/cowberry, dwarf birch - sphagnum larch forests; more seldom true moss, sedge- sphagnum and grassybog spruce forests are met; cowberry, shrub/ lichen pine forests occur in fragments.

Fires are mainly elongated in shape. Very large fires having the area of several tens of thousands hectares have round shapes. But both have prominences and branches of different size and shape. Such fire shape is caused by presence of large areas with relatively homogenous fuels and slopes having various steepness. The prominences and branches are formed when the fire is spreading under the influence of wind along slopes covered by larch stands with shrub/lichen ground vegetation. In the lowlands and river/brook valleys covered by dwarf birch- sphagnum larch forests as well as sedge sphagnum and grassybog spruce forests fires spread very slowly; these areas can often stop the fire spread.

Inspection of numerous areas burned shows that river valleys with open water surface having width of $10-20 \mathrm{~m}$ can be as the reliable barrier to stop back and flank edges of fires. Rivers and brooks less than $10 \mathrm{~m}$ wide the fire crosses through downed wood. Crossing the Lower Tunguska River by large fires has not been observed. Usually fires spread through frontal and flank edges. However it often can be observed when fire front quickly reaches some impassable barrier and stops, then only the back edge spreads. In such case all burned area is covered by smoke and it is difficult to orientate here.

\section{The criteria for extreme fire situation in forests of Central Siberia}

Weather condition is a one of the determining factor causing extreme fire danger in forests. Solar radiation, precipitation, air temperature and other parameters define the drying intensity of forest fuel. Forest fuel moisture content correlates with fire danger index, and characterizes the fuel ability to burn indirectly.

Within vast areas of the boreal forest (or taiga) of Central Siberia it is necessary to use the data that reflects the dynamics of the weather fire danger daily and widely (Ponomarev, Sukhinin, 2000; Ponomarev et al., 2008; Rubtsov et al., 2010). Currently, in Siberia this monitoring cannot be realized only by using the information from rare set of weather stations. An alternative technology was proposed (Ponomarev, Sukhinin, 1999; Ponomarev, Sukhinin, 2003) using remote sensing data in the thermal range for assessment and mapping of fire danger index. Classical empirical relation proposed by V.G. Nesterov (1949) and improved in Leningrad Forestry Research Institute (LenNIILKh) (Gritsenko, Shabunina, 1967) was used for the calculation of fire danger index.

$$
P V_{j}=\left\{\begin{array}{c}
\xi \cdot P V_{j-1}, \text { in case of precipitations } \\
P V_{j-1}+t_{j}\left(t_{j}-\tau_{j}\right), \text { for daily calculation }
\end{array},\right.
$$

where $\tau$ - dew point temperature, ${ }^{\circ} \mathrm{C} ; t$ - air temperature, ${ }^{\circ} \mathrm{C} ; \xi$ - precipitation coefficient; $P V_{j-1}$ and $P V_{j}$ - Nesterov fire danger index for previous and current days.

The technology was proposed in V.N. Sukachev Institute of Forest SB RAS for generating daily fire danger maps by using multispectral images from NOAA satellites. Imagery of NOAA/AVHRR instrument have spatial resolution of $1.1 \mathrm{~km}$, wide field of view (about 3 thousand $\mathrm{km}$ across swath), and high periodicity of the data renewing ( $4-6$ hour). 
Data from three AVHRR channels are used in visible, near infrared and thermal IR range, which allows restoring the temperature field of earth surface. Operational schemes of fire danger have a spatial resolution of $1-4 \mathrm{~km}$ over the territory of Central Siberia, which is significantly higher than interpolating of weather stations data. This information is one of the most important layers in the geographic information system (GIS) of forest fire monitoring.

Modality of Nesterov index curve characterizes the type of development of weather fire danger situation. The mode covers a period of drying, which includes the time, when fire danger index exceeds the upper limit of the IV (high) fire danger class defined according to local fire danger scales. This interval is the time necessary for dominant fine fuels drying up to critical values. The drying period ranges from 150 to 200 hours according to experimental data (Lykov, 1968; Sofronov, Volokitina, 1990; Sukhinin, Ponomarev, 1998). Considering sunlight time duration and the day-to-night dynamics of the fuel moisture, estimated drying period lasts for 3-5 days (Sukhinin,
Ponomarev, 1998; Ponomarev, Sukhinin, 1999). The beginning and the end of the mode are determined by the lowest level of fire danger index.

Temporal and quantitative characteristics of modes on the fire danger index curve correspond to three scenarios of fire situation development. The condition determining the season type is expressed through the ratio of $S_{1}$ and $S_{2}$ the areas formed by fire danger index curve separated by fire danger level of IV class (Fig. 2). The curve modality is especially well expressed for the second and the third scenarios.

The scenario for the first type of fire seasons describes low fire danger level and low quantitative statistics of wildfires during fire season. The absence of modes on the fire danger index curve $\left(S_{1}=0\right)$ is a key feature of this type. Values of Nesterov index are within range of $2000-3000$, that correspond to low (II) or moderate (III) classes of fire danger. There is no long drying periods during fire season. Precipitation is evenly distributed over the fire season. Local fire protection divisions are able to control the fire situations successfully.

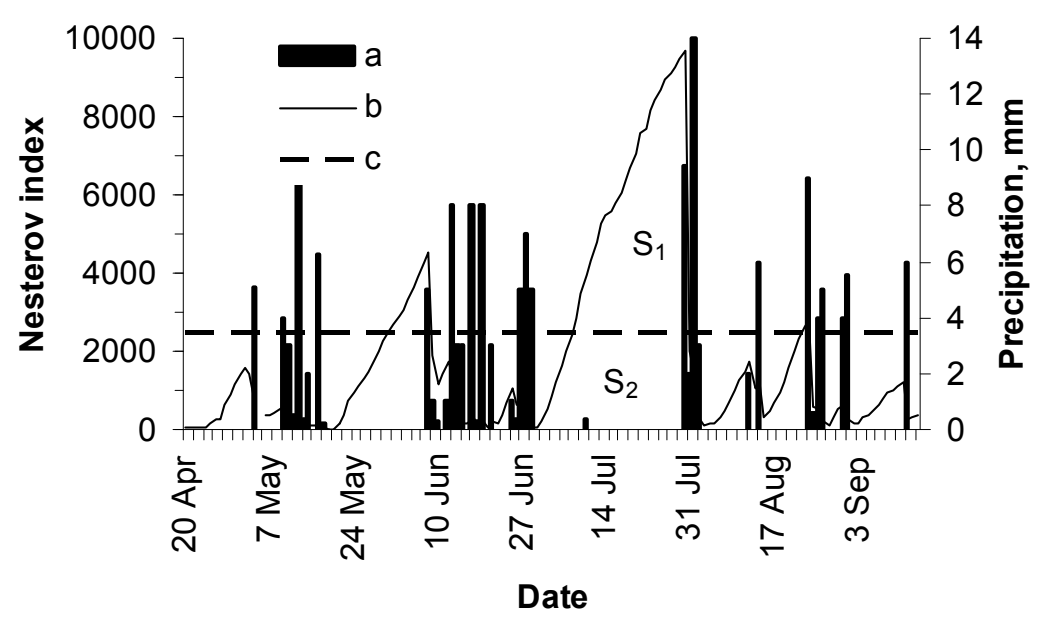

Fig. 2. Fire danger index dynamics for Bogutchany district of Krasnoyarsk Region, 1993. An example of extreme fire danger situation scenario: $a$ - precipitation, $b$ - Nesterov index, $c$ - Nesterov index for IV class of fire danger in region 
The second type scenario is typical for the seasons of moderate up to high fire danger level (IV or $\mathrm{V}$ classes of fire danger). The key feature of the type is $0<\mathrm{S}_{1}<\mathrm{S}_{2}$. Following to results of long term monitoring up to three modes can occur during a fire season in Central Siberia. Every mode is usually associated with increasing of forest fires number. In this case wildfires numbers and areas burned could be controlled by necessary level of fire prevention in region.

Scenario of third type is assigned to extreme fire seasons (Fig. 2). The key factor responsible for the occurrence of these fire seasons is $S_{1} \geq S_{2}$. The curve of fire danger index has one or two modes when wildfire situation develops according to the third scenario. Such kinds of seasons are characterized by an exceptionally high fire danger rate associated with extreme fire situation. Mass wildfires occurrences as well as extreme burned areas are usual. The situation with forest fires could reach very fast unmanageable stage, and will remain extreme for a long time during fire season.

In our opinion the technology and scenario description can be used for daily analysis of fire situation in the region, including short-term prediction, effective fire management decisions and the implementation of preventive measures by fire control services.

\section{Short-term forecasting}

of the fire season

The model of short-term fire danger forecasting can be described on the basis of average indicators considered for various scenarios of fire season. Nesterov index is evaluated by calculation using average values of meteorological parameters that are fixed for region under conditions of steady drying process without precipitation. This model based on daily iterations during the period of forecasting (Ponomarev, Sukhinin, 1999; Ponomarev, Sukhinin, 2002).

Fig. 3 shows the model curve describing the development of extreme fire situation. The proposed model is iterative - data correction for subsequent days based on the analysis of the previous period. Mostly it concerned to daily precipitation accounting. The range of limiting values of Nesterov index can be obtained using statistical information about the mode duration, as well as the minimum and the maximum air temperatures during the observed period for the region. So proposed approach allows us to estimate the beginning of extreme fire situation

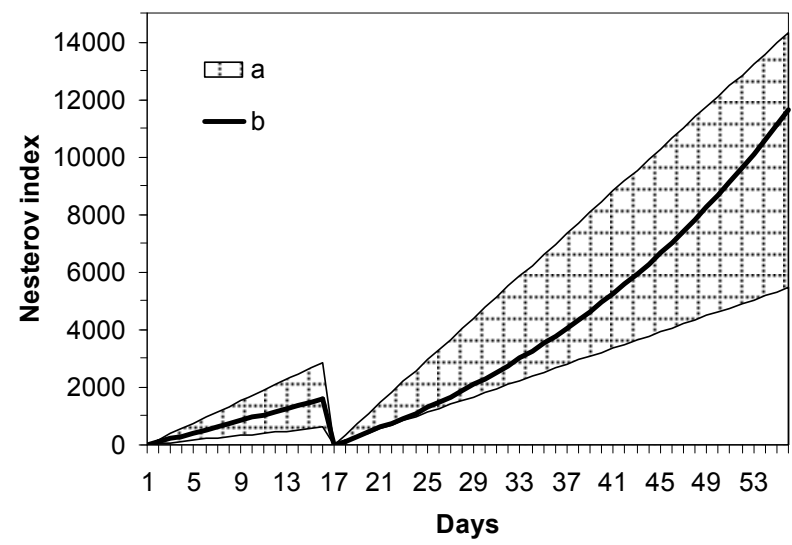

Fig. 3. An example of fire danger forecasting during extreme fire season. a - a range of limiting values, bpredictive curve 
that will be followed by an increase in the number of forest fires and approach the situation out of control.

The critical value of the number of active fires within the local forest area is $10-12$ events. In the conditions of previous long period of fuel drying, such threshold can be exceeded many times. Fire situation is followed by the massive outbreaks of wildfires, and often takes the form of extreme landscape fires on areas up to 100 thousand hectares.

Such situations have been observed in Central Siberia sporadically (Sukhinin, 2008; Balzter et al., 2010; Rubtsov et al., 2010; Ponomarev, 2010; Goldammer et al., 2013). Statistically Siberia and Far East region are under strong impact of wildfires as during 70th -80 th of last century and nowadays (Shvidenko, Shchepashchenko, 2013). In particular, in the Angara River region in 1996 after a 30-day drought, the number of fires has increased to 30 units during two days. In 2006 more than 50 forest fires were recorded in Evenkiya during 2 days. Similar situation was developed in 2012 in Western Siberia and in the
Evenkiya, and in 2013 in Yakutia (Ponomarev, Shvetsov, 2013). In such circumstances, even mobilization of additional fire control resources cannot provide the required level of fire situation control.

\section{Conclusion}

The large forest fires usually occur in the middle of prolonged droughts, when forest combustible materials dry out over large areas but the fast development of fire to large sizes in these circumstances affected especially by synoptic situations, accompanied by strong winds. In Central Siberia often large fires occur at intermediate synoptic situations that are not accompanied by strong winds, but are characterized by air masses with high temperatures and low humidity. Fire seasons scenarios are examined and an iterative model for short-term forecasting of extreme fire situations are proposed. Methodology for shortterm forecasting of landscape fires risk is offered based on satellite data simultaneously on the whole territory of Central Siberia.

\footnotetext{
The large fire is a fire covering an area of at least the landscape and consists of many types of fires, able to self-development and requires a special organization for its suppression (Valendik, 1990).

2 Catastrophic fire is a fire which has significant negative impacts on the sustainability of ecosystems and human assets (International multilingual fire management terminology, 2010).
}

\section{References}

1. Balzter H., Tansey K., Kaduk J., George Ch., Gerard F., Cuevas Gonzalez M., Sukhinin A. and Ponomarev Y. (2010) Fire/climate interactions in Siberia. In: Balzter H. (ed.) Environmental change in Siberia. Earth observation. Field studies and modeling. Advances in global change research, 40 (Part 1). Springer, p. 21-36.

2. Bondarenko A.L. (2013) Summer of 2013: Heat wave in Russia and floods in Pakistan. Science in Russia 2: 28-31 (in Russian).

3. Bondur V.G. (2011) Satellite monitoring of wildfires in Russia in abnormal drought conditions of 2010. Issledovanie Zemli iz Kosmosa (The Study of Earth from Space) 3: 3-13 (in Russian).

4. Breshkova T.V., Golubev A.D., Parshina L.I. (2011) Anomalous hydro-meteorological phenomena in Russian Federation in May, 2011. Meteorology and Hydrology 8: 109-111 (in Russian).

5. Chekmasova G.I. (2002) Weather in Russian Federation in August 2002. Meteorology and Hydrology 11: 106-107 (in Russian). 
6. Conard S.G., Sukhinin A.I., Stocks B.J., Cahoon D.R., Davidenko E.P., Ivanova G.A. (2002) Determining effects of area burned and fire severity on carbon cycling and emissions in Siberia. Climatic Change 55 (1-2): 197-211.

7. Goldammer J.G., Stocks B.J., Sukhinin A.I., Ponomarev E.I. (2013) Current fire regimes, impacts and the likely changes - II: Forest fires in Russia - Past and current trends. In: Goldammer J.G. (ed.) Vegetation fires and global change: challenges for concerted international action. A White Paper directed to the United Nations and international organizations. A publication of the Global Fire Monitoring Center (GFMC). Kessel Publishing House, p. 51-79.

8. Grechikhina A.P., Kiriyenko L.V., Naishuller, M.G. (2003) Anomalous hydro- meteorological phenomena in Russian Federation. Meteorology and Hydrology 11: 112-118 (in Russian).

9. Gritsenko M.V., Shabunina T.A. (1967) On the calculation of forest fire danger index: methodical instructions. Moscow: Gidrometeocentr SSSR (Weather Bureau of the USSR). 16 p. (in Russian).

10. Gudilin I.S. (ed.) (1987) Landscape map of the USSR. Scale: 1: 2500000 (in Russian).

11. International multilingual fire management terminology (2010). Global Fire Monitoring Center, 368 p. (http://www.fire.uni-freiburg.de/literature/RUS-MON-GER-ENG-Glossary-Web.pdf).

12. Isaev A.S., Maltsev V.N., Semenov Y.M. (eds.) (1994) Atlas of the Krasnoyarsk Region and the Republic of Khakassia. Novosibirsk: Roskartographia, 84 p. (in Russian).

13. Korovin G.N. (1996) Analysis of the distribution of forest fires in Russia. In: Goldammer J.G., Furyaev V.V. (eds.). Fire in ecosystems of boreal Eurasia. Kluwer Acad. Publ. Dordrecht, p. 112-128.

14. Kotilevskaya A.M. (2010) Weather in Russian Federation. Meteorology and Hydrology 10: 103106 (in Russian).

15. Loupian E.A., Mazurov A.A., Flitman E.V., Ershov D.V., Korovin G.N., Novik V.P., Abushenko N.A., Altyntsev D.A., Koshelev V.V., Tashchilin S.A., Tatarnikov A.V., Csiszar I., Sukhinin A.I., Ponomarev E.I., Afonin S.V., Belov V.V., Matvienko G.G. and Loboda T. (2006) Satellite monitoring of forest fires in Russia at federal and regional levels. Mitigation and Adaptation Strategies for Global Change 11(1): 113-145.

16. Lykov A.V. (1968) Theory of drying. Moscow: Energy, 180 p. (in Russian).

17. Nesterov V.G. (1949) Forest fire danger and methods of its assessment. Moscow: Goslesbumizdat, 76 p. (in Russian).

18. Ponomarev E.I. (2010) Zoning of forest territory of Russia on the basis of natural fire danger and anthropogenic impact levels. Journal of International Scientific Publications: Ecology \& Safety 4 (Part 2): 68-79.

19. Ponomarev E.I., Shvetsov E.G. (2013) Characteristics of vegetation fire categories in Siberia, according to satellite-based and other observations. Issledovanie Zemli iz Kosmosa (The Study of Earth from Space) 5: 45-54 (in Russian).

20. Ponomarev E.I., Sukhinin A.I. (1999) Criteria for extreme fire situation in forests of Krasnoyarsk Region. Siberian Bulletin of Fire Safety 2: 24-30. (in Russian).

21. Ponomarev E.I., Sukhinin A.I. (2000) Complex assessment of fire danger and forecasting of energy parameters of wildfires using geographic information databases. Computational technologies. Special issue devoted to the development of GIS and remote sensing in the SB RAS 5: 58-68 (in Russian). 
22. Ponomarev E.I., Sukhinin A.I. (2002) Methodology for mapping and medium-term forecasting of weather fire danger in forests. Geography and Natural Resources 4: 112-117. (in Russian).

23. Ponomarev Y.I., Sukhinin A.I. (2003) Methods for mapping and medium-range forecasting of fire danger in forests on the basis of weather conditions. Mapping Sciences and Remote Sensing 40(4): 304-310.

24. Ponomarev E.I., Bezmaternykh P.F., Ivanov V.A. (2008) Peculiarities of the geographical distribution of wildfires in Central Siberia. Lesnoye Khozyastvo (Forestry) 1: 46-47. (in Russian).

25. Rubtsov A.V., Sukhinin A.I., Vaganov E.A. (2010) Actual fire danger classification of the Siberian territories using satellite data. Journal of Siberian Federal University. Biology 3(1): 30-39 (in Russian).

26. Satina N.V. (2012) Weather in Russian Federation in August 2012. Meteorology and Hydrology 11: 103-107 (in Russian).

27. Shvidenko A.Z., Shchepashchenko D.G., Vaganov E.A., Sukhinin A.I., Maksyutov Sh., McCallum I., and Lakyda I.P. (2011) Impact of wildfire in Russia between 1998-2010 on ecosystems and the global carbon budget. Doklady Earth Sciences 441(2): 1678-1682.

28. Shvidenko A.Z., Shchepashchenko D.G. (2013) Climate changes and forest fires in Russia. Lesovedenije (Forest Science) 5: 50-61 (in Russian).

29. Sofronov M.A. (1967) Forest fires in the mountains of southern Siberia. Moscow: Nauka, 149 p. (in Russian).

30. Sofronov M. A., Volokitina A.V. (1990) Forest fires zoning in the taiga zone. Novosibirsk: Nauka, 205 p. (in Russian).

31. Soja A.J., Sukhinin A.I., Cahoon Jr. D. R., Shugart H.H., Stackhouse P.W. (2004) AVHRR-derived fire frequency, distribution and area burned in Siberia. International Journal of Remote Sensing 25(10): 1939-1960, doi:10.1080/01431160310001609725.

32. Sukhinin A.I. (1996) The system of satellite monitoring of forest fires in Krasnoyarsk Region. Siberian Ecological Journal 3(1): 85-92 (in Russian).

33. Sukhinin A.I. (2008) Space monitoring and analysis of catastrophic fires in Central Siberia and Far East. Tohoku University, North-East Asia, A la Carte 19: 19-23.

34. Sukhinin A.I., Ponomarev E.I. (1998) Forest fuels moisture content assessment by radiative temperature. M.: VINITI, 1144-B98, 36 p. (in Russian).

35. Sukhinin A.I., Ivanov V.V., Ponomarev E.I., Slinkina O.A., Cherepanov A.V., Pavlichenko E.A., Romasko V.Y. and Miskiv S.I. (2003) The 2002 fire season in the Asian part of the Russian Federation: A view from space. Int. Forest Fire News 28: 18-28.

36. Valendik E.N. (1990) Large fires control. Moscow: Nauka, 193 p. (in Russian).

37. Valendik E.N. (1996) Temporal and spatial distribution of forest fires in Siberia. In: Goldammer J.G., Furyaev V.V. (eds.). Fire in ecosystems of boreal Eurasia. Dordrecht: Kluwer Acad. Publ., p. 129-138.

38. Vasiliev E.V., Lukyanov V.I., Naishuller M.G. (2006) Features of the atmospheric circulation of the northern hemisphere. Meteorology and Hydrology 9: 109-118 (in Russian). 